Bożena Krogulska

PRACA ORYGINALNA

Renata Matuszewska

Marta Bartosik

Adam Krogulski

Maciej Szczotko

Dorota Maziarka

\title{
ANALIZA WYSTĘPOWANIA DOLEGLIWOŚCI I OBJAWÓW ZE STRONY UKŁADU ODDECHOWEGO U OSÓB ZATRUDNIONYCH W PRZEMYŚLE NA STANOWISKACH PRACY GENERUJACYCH AEROZOL WODNY. BADANIA PILOTAŻOWE JAKOŚCI MIKROBIOLOGICZNEJ POWIETRZA I WODY TECHNOLOGICZNEJ
}

\author{
RESPIRATORY SYMPTOMS AMONG INDUSTRIAL WORKERS EXPOSED TO WATER AEROSOL. \\ A PILOT STUDY OF PROCESS WATER AND AIR MICROBIAL QUALITY
}

Narodowy Instytut Zdrowia Publicznego - Państwowy Zakład Higieny / National Institute of Public Health - National Institute of Hygiene, Warszawa, Poland

Zakład Higieny Środowiska / Departament of Environmental Hygiene

\begin{abstract}
STRESZCZENIE
Wstẹp: Przedmiotem badań była ocena czestości występowania dolegliwości ze strony układu oddechowego osób narażonych na aerozol wodny w zakładach przemysłowych oraz wstępna ocena skażenia mikrobiologicznego powietrza i wody technologicznej. Materiał i metody: Opracowano ankietę, która zawierała pytania ukierunkowane na warunki pracy oraz występowanie objawów zmian w układzie oddechowym, które mogą sugerować zapalenie płuc, w tym legionelozę. Badania ankietowe przeprowadzono w 9 zakładach mechanicznej obróbki szkła, wzięło w nich udział 131 osób. Badania mikrobiologiczne powietrza i wody wykonano w 1 wybranym zakładzie. W próbkach wody oznaczano obecność bakterii z rodzaju Legionella według PN-EN ISO 11731-2:2008 oraz ogólną liczbę mikroorganizmów według PN-EN ISO 6222:2004. Badania ogólnej liczby pleśni i grzybów w powietrzu prowadzono metodą zderzeniową. Wyniki: Występowanie ostrych dolegliwości ze strony układu oddechowego odnotowano u 28,2\% osób, a dolegliwości przewlekłe u $29 \%$ osób. Najczęściej występującą dolegliwością był długotrwały kaszel, który zgłaszało $16 \%$ badanych. Rzadziej zgłaszana była duszność wysiłkowa (12,9\%), świszczący oddech (12,2\%) oraz ból w klatce piersiowej (10,7\%). Stwierdzono zwiększone ryzyko kaszlu oraz zespołu ostrych objawów, które mogą sugerować zapalenie płuc w grupie osób wykonujących pracę w odległości do $20 \mathrm{~m}$ od źródła aerozolu wodno-powietrznego, w porównaniu z pozostałymi pracownikami. Badania mikrobiologiczne wody technologicznej wykazały obecność bakterii Legionella pneumophila w liczbie przekraczającej 1000 jtk/100 ml. Jednocześnie odnotowano wysoką liczbę bakterii i grzybów w powietrzu (> $\left.1000 \mathrm{jtk} / \mathrm{m}^{3}\right)$, których źródłem prawdopodobnie była woda technologiczna. Wnioski: Uzyskane dane ankietowe oraz badania pilotażowe skażenia mikrobiologicznego wody i powietrza na stanowiskach pracy wskazują na istnienie realnego zagrożenia zdrowia pracowników narażonych na wdychanie skażonego aerozolu wodnego. Med. Pr. 2013;64(1):47-55
\end{abstract}

Słowa kluczowe: stanowisko pracy, Legionella, aerozole, mikrobiologia, układ oddechowy, badania ankietowe

\begin{abstract}
Background: The frequency of respiratory symptoms in workers exposed to water aerosol was evaluated along with the preliminary assessment of microbiological contamination of air and water used in glass processing plants. Material and Methods: A questionnaire survey was conducted in 131 workers from 9 glass processing plants. Questions focused on working conditions, respiratory symptoms and smoking habits. A pilot study of air and water microbiological contamination in one glass processing plant was performed. Water samples were tested for Legionella in accordance with EN ISO 11731-2:2008 and for total colony count according to PN-EN ISO 6222:2004. Air samples were tested for total numbers of molds and mildews. Results: During the year preceding the survey acute respiratory symptoms occurred in $28.2 \%$ of participants, while chronic symptoms were reported by $29 \%$ of respondents. Increased risks of cough and acute symptoms suggestive of pneumonia were found among the respondents working at a distance up to $20 \mathrm{~m}$ from the source of water aerosol compared to other workers $(\mathrm{OR}=2.7)$, with no difference in the frequency of other symptoms. A microbiological analysis of water samples from selected glass plant revealed the presence of L. pneumophila,
\end{abstract}

Publikacja opracowana na podstawie wyników II etapu programu wieloletniego „Poprawa bezpieczeństwa i warunków pracy” finansowanego w latach 2011-2013 w zakresie badań naukowych i prac rozwojowych ze środków Ministerstwa Nauki i Szkolnictwa Wyższego/ /Narodowego Centrum Badań i Rozwoju. Koordynator programu: Centralny Instytut Ochrony Pracy - Państwowy Instytut Badawczy. 
exceeding $1000 \mathrm{cfu} / 100 \mathrm{ml}$. The number of bacteria and fungi detected in air samples (above $1000 \mathrm{cfu}^{\mathrm{m}} \mathrm{m}^{3}$ ) suggested that water aerosol at workplaces can be one of the sources of the air microbial contamination. Conclusions: The questionnaire survey revealed an increased risk of cough and acute symptoms suggestive of pneumonia in the group working at a shortest distance form the source of water aerosol. Med Pr 2013;64(1):47-55

Key words: workplace, Legionella, aerosols, microbiology, respiratory system, self report

Adres autorów: Narodowy Instytut Zdrowia Publicznego - Państwowy Zakład Higieny, Zakład Higieny Środowiska, ul. Chocimska 24,01-791 Warszawa, e-mail: bkrogulska@pzh.gov.pl

Nadesłano: 19 października 2012, zatwierdzono: 5 grudnia 2012

\section{WSTĘP}

Wyniki badań prowadzonych w ostatnich latach w wielu krajach wskazują, że około 87\% czasu ludzie przebywają w pomieszczeniach budynków, z czego duża część przypada na czas spędzony w miejscu pracy. Jednym z czynników mogących stwarzać zagrożenie dla zdrowia na stanowiskach pracy są urządzenia wydzielające skażony aerozol wodny do powietrza. Mikroorganizmy występujące naturalnie w powietrzu są w większości nieszkodliwe dla człowieka. W przypadku występowania dodatkowego źródła skażenia, wynikającego z obecności mikroorganizmów patogennych w wodzie technologicznej na stanowiskach pracy, ryzyko wystąpienia zakażeń układu oddechowego jest jednak większe $(1,2)$. Odpowiednio wysoka wilgotność powietrza i długotrwały czas ekspozycji pracownika zakładów przemysłowych na tego typu zagrożenia może wiązać się z licznymi dysfunkcjami układu oddechowego, takimi jak astma, alergiczny nieżyt błony śluzowej nosa, zapalenie oskrzeli, niewydolność oddechowa, choroby układu sercowo-naczyniowego, nieżyty przewodu pokarmowego, gruźlica, reakcje alergiczne, a także zapalenie zatok obocznych nosa, zapalenie spojówek i ostre infekcje wirusowe górnych dróg oddechowych (3). Zagrożenie dla zdrowia ludzi mogą stwarzać nie tylko same drobnoustroje, ale także ich metabolity - endotoksyny i mykotoksyny, które w bioaerozolach odgrywają znaczącą rolę, powodując reakcje zapalne i przyczyniając się do pogorszenia funkcji płuc (3-6).

Jednym z mikroorganizmów, który może występować w bioaerozolu i może stanowić poważne zagrożenie dla zdrowia ludzi, są bakterie z rodzaju Legionella (7-9). Zakażenie tymi bakteriami następuje poprzez wdychanie zawierającego te mikroorganizmy aerozolu wodnego, którego źródłem są kolonizowane przez nie instalacje wodne różnego typu i przeznaczenia $(9,10)$. Podatne są na nią zwłaszcza systemy przesyłu wody ciepłej o temperaturze $20-40^{\circ} \mathrm{C}$, których konstrukcja sprzyja zastojom wody i tworzeniu się obrostów mikrobiologicznych na wewnętrznej powierzchni urządzeń i systemów wodnych $(1,2,8,10-12)$. Obraz kliniczny choroby rozwijającej się w następstwie zakażenia drogą wziewną może przybierać formę legionelozy płucnej, przebiegającej w postaci zapalenia płuc, zwykle o ciężkim przebiegu, z dominującymi objawami ze strony układu oddechowego lub tzw. gorączki Pontiac, która przebiega z podwyższoną ciepłotą ciała oraz rozlanymi bólami mięśniowymi i stawowymi $(1,2)$.

$\mathrm{Z}$ uwagi na rozpowszechnienie kolonizacji instalacji wodnych ryzyko zakażenia dotyczy dużej części populacji, w tym osób narażonych na wdychanie skażonego aerozolu wodnego $\mathrm{w}$ trakcie wykonywania pracy zawodowej. Opisywano przypadki zakażenia bakteriami z rodzaju Legionella m.in. u pracowników zakładów opieki zdrowotnej i gabinetów stomatologicznych (13-16), obsługi systemów klimatyzacyjnych i chłodzących (17), pracowników oczyszczalni ścieków (18) oraz zatrudnionych przy obsłudze różnego rodzaju urządzeń czyszczących i myjących w przemyśle maszynowym i spożywczym (19-22). Stosowane w zakładach mechanicznej obróbki szkła urządzenia myjące powodują powstawanie aerozolu wodnego, na który narażeni są pracownicy zatrudnieni przy ich obsłudze oraz $\mathrm{w}$ ich bezpośredniej bliskości, jednak nie ma danych o rejestrowanych wśród nich przypadkach legionelozy.

Celem przedstawianej pracy była analiza rodzaju i częstości występowania dolegliwości ze strony układu oddechowego. Została ona przeprowadzona na podstawie badania ankietowego, którym objęto pracowników wybranych zakładów mechanicznej obróbki szkła narażonych na aerozol wodny. Wstępnie oceniono także jakość mikrobiologiczną powietrza na stanowiskach pracy i wody pobranej z urządzeń generujących aerozol wodny (badania pilotażowe). 


\section{MATERIA I METODY}

\section{Badanie ankietowe}

Badaniem objęto ogółem 131 osób zatrudnionych w 9 zakładach mechanicznej obróbki szkła należących do przedsiębiorstwa, które ma oddziały w różnych częściach Polski. Badanie ankietowe przeprowadzano na stanowiskach pracy. Uzyskano odpowiedzi od wszystkich pracowników danej zmiany zatrudnionych w dniu badania bezpośrednio przy produkcji, którzy wyrazili zgodę na wzięcie udziału w badaniu. Ankieta obejmowała 5 grup danych:

1. Dane demograficzne: wiek, płeć, miejsce zamieszkania (miasto/wieś).

2. Dane dotyczące pracy zawodowej i rekreacji:

- czas pracy w danym zakładzie i na określonym stanowisku,

- rodzaj wykonywanych czynności,

- odległość stanowiska pracy od źródła aerozolu wodnego,

- wywiady dotyczące wcześniejszego zatrudnienia $\mathrm{z}$ uwzględnieniem narażenia na:

- potencjalnie szkodliwe czynniki biologiczne, chemiczne i fizyczne,

- korzystanie $\mathrm{z}$ natrysku $\mathrm{w}$ miejscu pracy (co najmniej 3 razy w tygodniu),

- korzystanie $\mathrm{z}$ rekreacji wodnej (co najmniej 1 raz w roku: basen kąpielowy, basen $z$ hydromasażem i inne).

3. Dane dotyczące stwierdzanych w przeszłości chorób układu oddechowego, hospitalizacji $\mathrm{z}$ ich powodu oraz długotrwałych dolegliwości, które obejmowały:

- kaszel utrzymujący się przez co najmniej 3 miesiące w ciągu 2 ostatnich lat,

- stałą lub nawracającą duszność wysiłkową, występującą systematycznie i odczuwaną nie rzadziej niż co 4 tygodnie,

- nawracający lub długotrwały ból w klatce piersiowej,

- świszczący oddech.

4. Dane dotyczące ostrych objawów ze strony układu oddechowego z towarzyszeniem objawów ogólnych lub bez nich, które występowały w ciągu minionego roku poprzedzającego badanie; występowanie zespołu objawów mogących odpowiadać legionelozie płucnej i gorączce Pontiac, na który składało się jednoczesne występowanie gorączki, dreszczy, bólów mięśniowych i/lub stawowych, bólów głowy, $\mathrm{z}$ towarzyszeniem duszności, kaszlu i ucisku w klatce piersiowej.
5. Dane dotyczące palenia papierosów odnosiły się do wieku w chwili rozpoczęcia palenia, przeciętnej liczby papierosów wypalanych dziennie, prób zaprzestania palenia i przerw w paleniu papierosów dłuższych niż 1 rok. W przypadku byłych palaczy pytano także o wiek, w którym zaprzestali palenia.

W trakcie przeprowadzania ankiety dokonywano pomiaru odległości stanowiska pracy od źródła aerozolu wodnego. Stanowiła ona podstawę różnicowania stopnia narażenia pracowników i pozwoliła na wyodrębnienie 2 grup badanych:

osoby zatrudnione $\mathrm{w}$ bezpośredniej bliskości urządzeń wytwarzających aerozol wodny, które przez większą część czasu pracy przebywały w odległości do $20 \mathrm{~m}$ od tego punktu;

osoby, których stanowisko pracy znajdowało się w odległości ponad $20 \mathrm{~m}$ od źródła aerozolu.

Odległość tę wybrano $\mathrm{z}$ uwagi na występujące u pierwszej z powyższych grup bezpośrednie narażenie na wdychanie aerozolu wodnego tuż po jego uwolnieniu $\mathrm{z}$ urządzeń technologicznych, które nie występowało u pracowników drugiej grupy. Następnie poddano ocenie różnice demograficzne występujące między powyższymi grupami, związane długością i przebiegiem zatrudnienia, różnice dotyczące palenia papierosów i zachowań mogących mieć wpływ na ryzyko zakażenia bakteriami z rodzaju Legionella, weryfikując ich istotność statystyczną testem chi-kwadrat.

W dalszym etapie badania dokonano porównania częstości występowania ostrych i przewlekłych dolegliwości ze strony układu oddechowego u pracowników obu powyższych grup z uwzględnieniem wieku, płci, palenia papierosów, stosując analizę regresji logistycznej i obliczając skorygowany iloraz szans przy 95-procentowym przedziale ufności.

\section{Badania mikrobiologiczne powietrza i wody technologicznej}

Próbki wody i powierza pobierano równocześnie w punktach na stanowiskach pracy, na których był generowany aerozol wodny. W próbkach wody technologicznej $(1000 \mathrm{ml})$ oznaczano obecność bakterii z rodzaju Legionella według normy PN-EN ISO 11731-2:2008 (23) oraz ogólną liczbę mikroorganizmów według PN-EN ISO 6222:2004 (24).

Badanie mikrobiologicznego zanieczyszczenia próbek powietrza prowadzono metodą zderzeniową przy użyciu aparatów: Micro Bio (Air Sampler MB 1 plus, prod. De Ville, Wielka Brytania) i MAS-100 (prod. Merck, Niemcy). Wykonano oznaczenia w kie- 
runku ogólnej liczby bakterii oraz ogólnej liczby pleśni i grzybów. Objętość pobieranych próbek powietrza wynosiła 100-300 l dla ogólnej liczby bakterii, pleśni i grzybów.

\section{WYNIKI}

Badaniami ankietowymi objęto ogółem 131 pracowników w wieku 18-57 lat (średnia: 32,1 lat) zatrudnionych bezpośrednio przy produkcji, w tym 113 mężczyzn (86,3\%) i 18 kobiet (13,7\%). Czas zatrudnienia osób badanych wynosił od 3 miesięcy do 15 lat (średnia: 4,4 roku). W badanej grupie papierosy paliło łącznie 68 osób $(51,9 \%)$. Byli palacze stanowili 25,2\% ankietowanych, natomiast niepalący - 22,9\%. Łącznie grupa osób kiedykolwiek palących liczyła 101 osób (71,1\%). Liczba wypalanych papierosów wynosiła przeciętnie 7,3 paczkolat. Z natrysków znajdujących się na terenie zakładów pracy korzystało co najmniej 3 razy tygodniowo 58 badanych $(44,2 \%)$, a basen kąpielowy lub aquapark był odwiedzany co najmniej raz w roku przez 69 osób (52,7\%). Odległość stanowisk pracy od źródeł aerozolu wynosiła 1-200 m (średnia: 40,1).

Ostre dolegliwości ze strony układu oddechowego $\mathrm{w}$ ciągu roku poprzedzającego badanie zgłosiło 37 badanych $(28,2 \%)$. Przeważały objawy nieżytu górnych dróg oddechowych - katar z niedrożnością nosa, ból gardła, kaszel, niekiedy z towarzyszeniem podwyższonej ciepłoty ciała. $U$ żadnego $z$ badanych objawy te nie trwały dłużej niż 3 tygodnie. Z powyższej grupy 7 osób zgłaszało wystąpienie zespołu objawów mogących nasuwać podejrzenie legionelozy, w tym postaci płucnej tej choroby. Na zespół składało się jednoczesne występowanie podwyższonej ciepłoty ciała, kaszlu, duszności, bólu lub ucisku w klatce piersiowej oraz rozlanych bólów mięśniowych i stawowych. Należy jednak podkreślić, że powyższy niespecyficzny zespół nie może stanowić podstawy do rozpoznania legionelozy, lecz co najwyżej wskazywać na taką możliwość. Żaden $\mathrm{z}$ ankietowanych pracowników $\mathrm{w}$ trakcie zatrudnienia $\mathrm{w}$ omawianych zakładach nie wymagał leczenia szpitalnego z powodu dolegliwości czy choroby układu oddechowego.

Występowanie przewlekłych dolegliwości ze strony układu oddechowego zgłosiło ogółem 38 badanych (29\%). Najczęściej występującą dolegliwością był długotrwały kaszel, który zgłaszało $16 \%$ badanych, spośród których $62,3 \%$ było palaczami papierosów. Rzadziej zgłaszana była nawracająca duszność wysiłkowa $(12,9 \%)$, świszczący oddech $(12,2 \%)$ i ból w klatce piersiowej $(10,7 \%)$.
Odległość stanowiska pracy od źródła aerozolu wodnego przyjęto jako podstawę zróżnicowania narażenia pracowników na ten czynnik. Wyodrębniono grupę osób zatrudnionych w bezpośredniej bliskości źródła aerozolu wodnego, które przez większą część pracy znajdowały się w odległości od niego nieprzekraczającej $20 \mathrm{~m}$, oraz grupę osób, których stanowiska pracy znajdowały się w odległości większej niż 20 m od źródła aerozolu. Liczba pracowników w powyższych grupach była podobna (odpowiednio: 64 osoby i 67 osób).

Porównanie danych demograficznych dotyczących zatrudnienia oraz zachowań mogących wiązać się $\mathrm{z}$ ryzykiem zakażenia bakteriami Legionella w obu grupach oraz ocena istotności statystycznej różnic przy pomocy testu chi-kwadrat wykazały, że nie ma różnic dotyczących wieku, procentowego udziału osób palących papierosy i byłych palaczy, czasu zatrudnienia w zakładzie obróbki szkła, częstości zamieszkania w mieście oraz korzystania z basenu kąpielowego i masaży wodnych. W obu grupach zaznaczała się przewaga mężczyzn, natomiast ich udział był większy w grupie osób wykonujących pracę w pobliżu źródła aerozolu wodnego $(\mathrm{p}<0,05)$. Osoby z tej grupy częściej korzystały z prysznica na terenie zakładu pracy (tab. 1).

W dalszym etapie badania - stosując analizę regresji logistycznej i wyliczając skorygowany iloraz szans (odds ratio) dla 95\% przedziału ufności - porównano częstość ostrych i przewlekłych dolegliwości ze strony układu oddechowego we wspomnianych wyżej 2 badanych grupach zatrudnionych. Zostały one wyodrębnione na podstawie odległości stanowiska pracy od źródła aerozolu wodnego, $\mathrm{z}$ uwzględnieniem wieku, płci i palenia papierosów (tab. 2).

W wytypowanym zakładzie obróbki szkła wykonano pilotażowe badania mikrobiologiczne wody technologicznej (5 próbek) w kierunku ogólnej liczby mikroorganizmów w $30^{\circ} \mathrm{C}$ i pałeczek Legionella. Próbki wody pobrano $\mathrm{z}$ linii technologicznych - otwartych zbiorników myjek pionowych (4 próbki) i zbiornika otwartego szlifierki poziomej. Wyniki badań wykazały obecność bakterii z rodzaju Legionella w próbkach wody pobranych $\mathrm{z}$ otwartych zbiorników myjek pionowych, a ich liczba wynosiła od $7,1 \times 10^{3} \mathrm{jtk} / 100 \mathrm{ml}$ do $2,9 \times 10^{4} \mathrm{jtk} / 100 \mathrm{ml}$. Nie stwierdzono obecności najbardziej niebezpiecznej pod względem zdrowotnym Legionella pneumophila serogrupy 1 (sg1), a wszystkie wyizolowane szczepy oznaczono jako Legionella pneumophila sg 2-14. Odnotowana ogólna liczba mikroorganizmów w temperaturze inkubacji $30^{\circ} \mathrm{C}$ wynosiła od $3,7 \times 10^{3} \mathrm{jtk} / \mathrm{ml}$ do $3,9 \times 10^{5} \mathrm{jtk} / \mathrm{ml}$. Temperatura wody 
Tabela 1. Charakterystyka badanej grupy pracowników zakładów obróbki szkła z uwzględnieniem odległości stanowiska pracy od źródła aerozolu wodnego

Table 1. Characteristics of the study groups of workers employed in glass processing plants by the workplace distance from the source of water aerosol

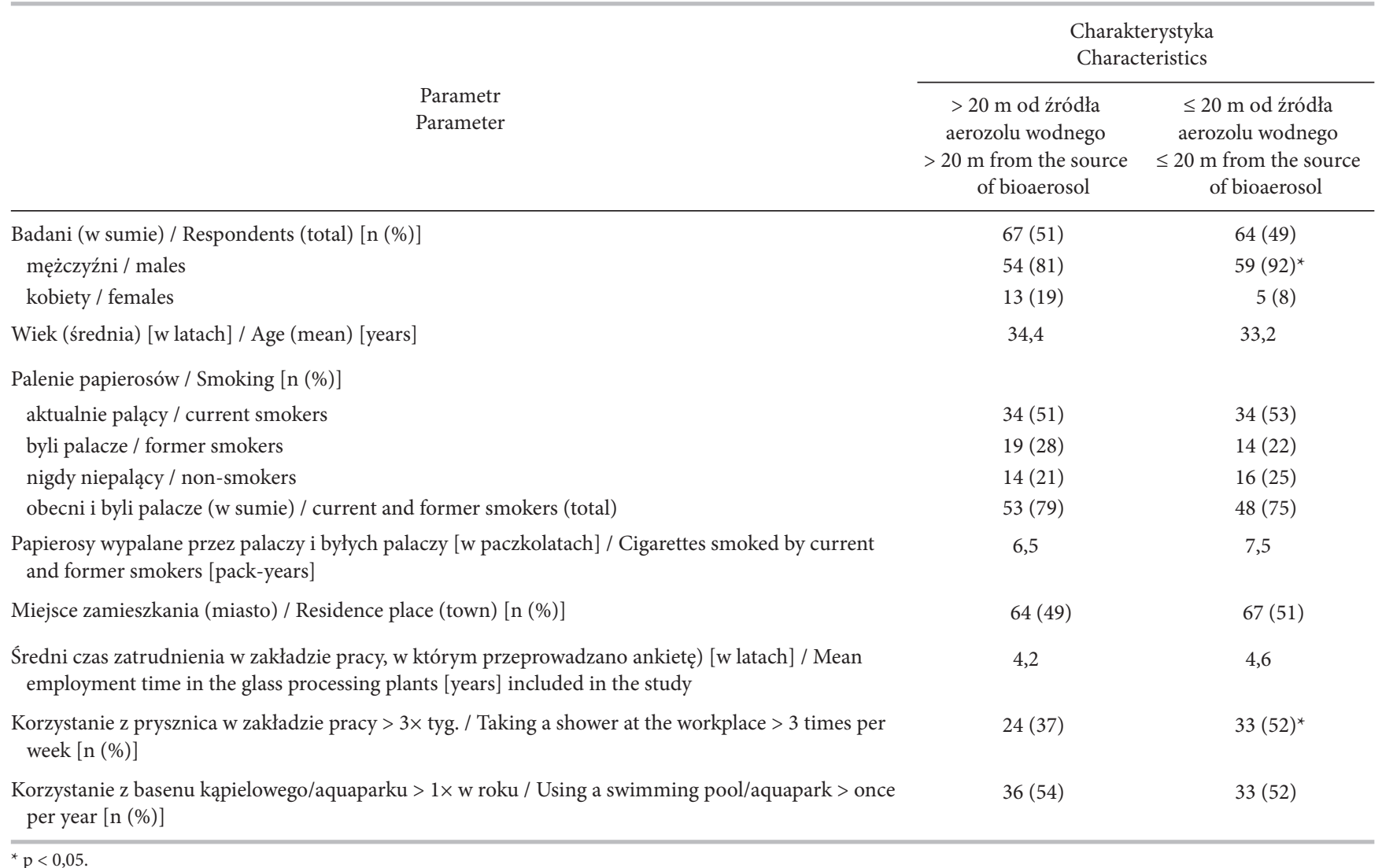

Tabela 2. Częstość występowania dolegliwości ze strony układu oddechowego w zależności od odległości stanowiska pracy od źródła generowanego aerozolu wodnego

Table 2. Frequency of respiratory symptoms in the groups of respondents working at a distance up to and above $20 \mathrm{~m}$ from the source of water aerosol

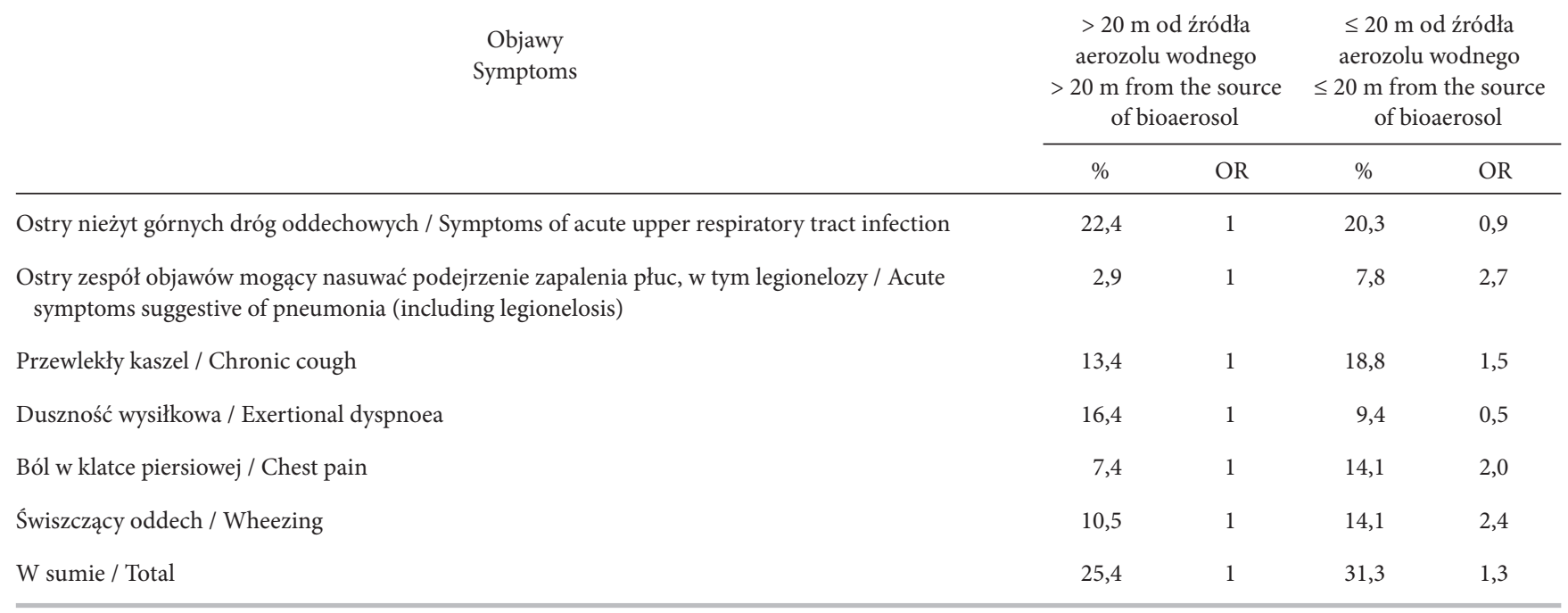

OR - iloraz szans / odds ratio. 
pobranych próbek ze zbiorników mycia wstępnego wynosiła $34,7-42,5^{\circ} \mathrm{C}$, a w zbiornikach mycia zasadniczego $-25,4-30,7^{\circ} \mathrm{C}$. Temperatura wody w zbiorniku zasilającym szlifierkę poziomą wynosiła $29,6^{\circ} \mathrm{C}$.

W hali produkcyjnej, w celu oznaczenia ogólnej liczby bakterii oraz ogólnej liczby pleśni i grzybów pobrano do badań próbki powietrza w 4 punktach pomiarowych (w tym jednym kontrolnym). Wytypowano 3 urządzenia (szlifierka pozioma szkła, 2 myjki pionowe), które $\mathrm{w}$ trakcie pracy generują powstawanie aerozolu wodnego w bezpośrednim sąsiedztwie.

Oznaczenia mikrobiologiczne powietrza prowadzono w bezpośrednim sąsiedztwie urządzeń generujących aerozol podczas ich standardowej pracy oraz w punkcie oddalonym od wytypowanych maszyn co najmniej o $30 \mathrm{~m}$ (próbka kontrolna). W każdym punkcie pomiarowym oznaczano również temperaturę i wilgotność powietrza. Tylko $\mathrm{w}$ bezpośrednim sąsiedztwie jednej $\mathrm{z}$ analizowanych myjek pionowych (L-2) stwierdzono znacznie większe wysycenie powietrza parą wodną (wilgotność do $96,4 \%)$ niż w punkcie pomiarowym odległym od niej o $30 \mathrm{~m}(44,5 \%)$. W pozostałych 2 punktach wilgotność powietrza tylko nieznacznie przewyższała pomiar wykonany w punkcie usytuowanym na końcu hali i wynosiła przy szlifierce poziomej do $55 \%$ i przy myjce pionowej L-1 - 50\%. Temperatura we wszystkich punktach pomiarowych była zbliżona i wynosiła $22,1-25,8^{\circ} \mathrm{C}$.

W pobliżu obu myjek pionowych stężenie zarówno bakterii, jak i grzybów było wyższe od ich stężenia w punkcie kontrolnym. W przypadku badanych myjek pionowych odnotowane stężenie bakterii i grzybów w powietrzu (ok. $10^{3} \mathrm{jtk} / \mathrm{m}^{3}$ ) było równie wysokie jak stężenie tych drobnoustrojów w wodzie zasilającej urządzenia (średnia: $10^{4} \mathrm{jtk} / \mathrm{ml}$ ). Z kolei w przypadku szlifierki poziomej mimo odnotowanej wysokiej liczby mikroorganizmów w wodzie zasilającej $\left(>10^{5} \mathrm{jtk} / \mathrm{ml}\right)$ $\mathrm{w}$ próbkach badanego powietrza nie stwierdzono tak wysokiego zanieczyszczenia $\left(<5,0 \times 10^{2} \mathrm{jtk} / \mathrm{m}^{3}\right)$. W powietrzu w pobliżu szlifierki poziomej stężenia zarówno bakterii, jak i grzybów nie różniły się istotnie od wartości uzyskanych w punkcie kontrolnym (ryc. 1).

\section{OMÓWIENIE}

Zakłady obróbki szkła, w których przeprowadzono badanie, to centra produkcyjne wyposażone w najnowocześniejsze technologie. Badanie ankietowe oraz środowiskowe przeprowadzono w zakładach obróbki szkła, w których pracownicy zajmują się krojeniem, szlifowaniem szkła, wierceniem otworów w szkle, hartowaniem, polerowaniem szkła i montażem szyb zespolonych. Należy też podkreślić, że dokłada się tam niezbędnych starań w celu zapewnienia optymalnych warunków pracy. Specyfika produkcji wymaga stosowania otwartych zbiorników wodnych i urządzeń służących m.in. do schładzania wyrobów podczas ich obróbki. Woda wykorzystywana w procesach technologicznych, szczególnie w urządzeniach generujących aerozol wodny, może być poważnym źródłem zanieczyszczenia mikrobiologicznego powietrza wdychanego przez pracowników. W aerozolu wodnym mogą być obecne zarówno grzyby, jak i bakterie, w tym bakterie z rodzaju Legionella.

Analiza wyników badań ankietowych grupy osób pracujących w odległości do 20 m włącznie od źródła aerozolu wodno-powietrznego i powyżej $20 \mathrm{~m}$ od generowanego aerozolu pokazuje, że obie badane grupy cechuje znaczna przewaga mężczyzn, wysoki udział osób palących i znaczny odsetek zgłaszających dolegliwości

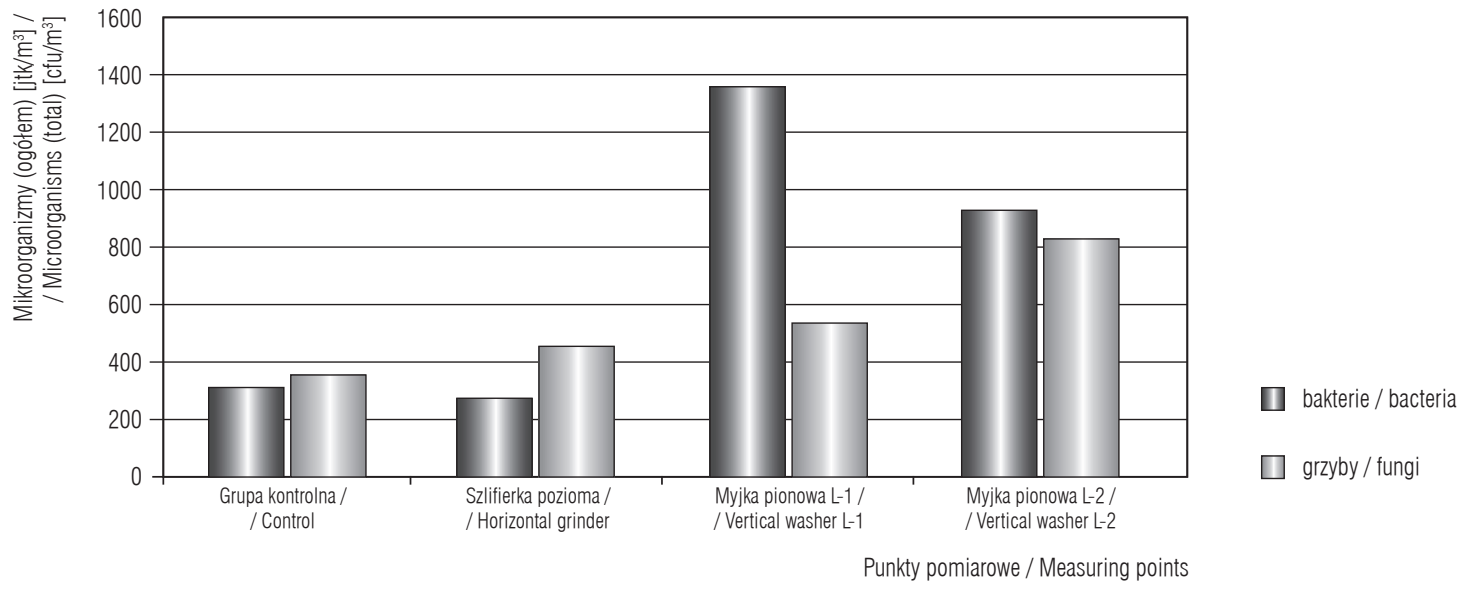

Ryc. 1. Ogólna liczba bakterii i grzybów w powietrzu w pobliżu urządzeń generujących aerozol wodny

Fig. 1. Total count of bacteria and fungi in the air around aerosol generating devices 
ze strony układu oddechowego, zarówno o charakterze ostrym, jak i przewlekłym. W ocenie porównawczej częstości dolegliwości ze strony układu oddechowego $\mathrm{w}$ obu grupach zwraca uwage przede wszystkim wyraźnie podwyższone ryzyko występowania nieswoistego zespołu ostrych objawów, które mogą sugerować m.in. legionelozę, dotyczące osób pracujących w bezpośrednim narażeniu na aerozol wodny. Osoby z tej grupy znamiennie częściej korzystały także z natrysków w zakładzie pracy, co może być dodatkowym, poza aerozolem wytwarzanym przez urządzenia przemysłowe, potencjalnym źródłem zakażenia, które wymaga kontroli.

Wspomniany wyżej niespecyficzny obraz kliniczny, opisywany przez pacjentów wypełniających ankietę, nie pozwala na ustalenie określonego rozpoznania i może jedynie wskazywać na możliwość wystąpienia legionelozy, w tym zwłaszcza gorączki Pontiac. Z uwagi na stosunkowo łagodny przebieg kliniczny choroby (żaden $\mathrm{z}$ badanych nie wymagał hospitalizacji, a jedynie 4 osoby były leczone antybiotykami) mniej prawdopodobna jest płucna postać legionelozy.

Wystąpienie opisanego zespołu dolegliwości może sugerować celowość skierowania pacjenta na serologiczne badania diagnostyczne, takie jak oznaczanie obecności antygenu pałeczek Legionella w moczu lub poziomu przeciwciał dla Legionella pneumophila w surowicy krwi. Może być też przesłanką do bardziej wnikliwego nadzoru nad stanem technicznym i higienicznym przemysłowych i sanitarnych urządzeń wodnych. W grupie osób bezpośrednio narażonych na aerozol wodny zwiększone było także (choć w mniejszym stopniu) ryzyko wystąpienia bólu w klatce piersiowej i długotrwałego kaszlu. Nie dotyczyło to natomiast duszności wysiłkowej ani częstości wystąpienia ostrych zakażeń górnych dróg oddechowych.

Specyfika narażenia pracowników w zakładach mechanicznej obróbki szkła poza ekspozycją na aerozol wodny obejmuje także inne czynniki, które mogą powodować występowanie dolegliwości ze strony układu oddechowego, w tym pył, jednak w tym przypadku narażenie dotyczy w równym stopniu obu badanych grup pracowników.

Przeprowadzenie audytu $\mathrm{w}$ zakładach przemysłowych mechanicznej obróbki szkła i zapoznanie się z rozmieszczeniem, konstrukcją, działaniem i stanem techniczno-sanitarnym urządzeń generujących aerozol wodny wykazało, że w urządzeniach (takich jak myjki, szlifierki, zbiorniki do magazynowania wody), będących wyposażeniem zakładów, występują sprzyjające warunki do namnażania się pałeczek Legionella i innych mikroorganizmów (temp. wody: $25,4-42,5^{\circ} \mathrm{C}$; biofilm, korozja, osady). Potwierdziły to wyniki badań mikrobiologicznych wody technologicznej, pobranej z tych urządzeń, w których wykazano zarówno wysoką ogólną liczbę bakterii $\left(10^{3}-10^{5} \mathrm{jtk} / \mathrm{ml}\right)$, jak i pałeczek Legionella pneumophila $\left(10^{3}-10^{4} \mathrm{jtk} / 100 \mathrm{ml}\right)$. Wyniki badań powietrza wykazały najwyższe stężenie bakterii, pleśni i grzybów (ok. $10^{3} \mathrm{jtk} / \mathrm{m}^{3}$ ) w pobliżu myjek pionowych. Obecność mikroorganizmów w wodzie technologicznej może więc stanowić poważne źródło skażenia powietrza na stanowiskach pracy.

Opublikowano liczne doniesienia o przypadkach zakażeń pałeczkami Legionella w obiektach przemysłowych (19,25-29). W raporcie z 1996 r. dotyczącym występowania legionelozy w Anglii i Walii odnotowano 6 zbiorowych zachorowań, które były następstwem zakażenia pracowników zakładów przemysłowych (27). Podobnie analizując 19 przypadków zachorowań na postać płucną legionelozy, zarejestrowanych w latach 2001-2004 w Trondheim w Norwegii, stwierdzono, że co najmniej $4 \mathrm{z}$ nich były związane $\mathrm{z}$ narażeniem w przemyśle. W 3 przypadkach bakterie Legionella izolowano $\mathrm{z}$ wody $\mathrm{z}$ wież chłodniczych, w jednym - z wody z prysznica na terenie zakładu przemysłowego (18).

Źródła zakażenia związane $\mathrm{z}$ przemysłowymi systemami wodnymi mogą stanowić zagrożenie nie tylko dla osób zatrudnionych w tych obiektach, ale także dla mieszkających w pobliżu. Wykazano to np. w przypadku 86 zachorowań, których przyczyną był zakażony aerozol wodny, wytwarzany przez wieże chłodnicze rafinerii naftowej we Francji (30). W latach 2002-2007 skażony aerozol wodny pochodzący z przemysłowych wież chłodniczych był przyczyną 44 ognisk legionelozy, obejmujących 1175 zachorowań (dane Europejskiej Grupy Roboczej ds. Zakażeń Legionella) (30).

Doniesienia o przypadkach legionelozy wśród pracowników zakładów przemysłowych dotyczą osób zatrudnionych $\mathrm{w}$ różnych gałęziach przemysłu, w tym obsługi przemysłowych oczyszczalni ścieków (29), pracowników zakładów ceramicznych (19), cukrowni (20), wytwórni urządzeń budowlanych, w której poddawano czyszczeniu elementy metalowe (26), oraz wytwórni silników samochodowych (21). W wodzie technologicznej w powyższych przypadkach bakterie L. pneumophila były wykrywane w liczbie od $10^{3} \mathrm{jtk} / \mathrm{ml}$ do $10^{5} \mathrm{jtk} / \mathrm{ml}$.

W Polsce istnieje obowiązek zgłaszania stwierdzonych przypadków legionelozy zgodnie z Ustawą z dnia 5 grudnia 2008 r. o zapobieganiu oraz zwalczaniu zakażeń i chorób zakaźnych u ludzi (31). W rozporządzeniu Ministra Zdrowia z dnia 22 kwietnia 2005 r. w sprawie szkodliwych czynników biologicznych dla 
zdrowia w środowisku pracy oraz ochrony zdrowia pracowników zawodowo narażonych na te czynniki, bakterie Legionella spp. i Legionella pneumophila zostały sklasyfikowane w grupie 2. jako czynniki, które moga wywołać choroby ludzi i być niebezpieczne dla pracowników (32).

\section{WNIOSKI}

1. Wykazano, że stosowane $\mathrm{w}$ zakładach przemysłowych urządzenia generujące aerozol wodny mogą być znaczącym źródłem skażenia powietrza na stanowiskach pracy.

2. Wykrycie w wodzie z urządzeń generujących aerozol wodny bakterii z rodzaju Legionella wskazuje na konieczność prowadzenia okresowego monitoringu jakości mikrobiologicznej wody i wdrożenia działań zapobiegających namnażaniu się mikroorganizmów w otwartych obiegach wody technologicznej.

3. Stwierdzenie $\mathrm{w}$ badaniu ankietowym większego ryzyka wystąpienia zespołu ostrych dolegliwości ze strony układu oddechowego oraz rozlanych bólów mięśni i stawów u pracowników zatrudnionych w bezpośredniej bliskości źródła aerozolu wodnego powinno skłaniać do uwzględnienia w diagnostyce różnicowej powyższych dolegliwości w tej grupie osób podejrzenia legionellozy, a zwłaszcza gorączki Pontiac. W tych przypadkach wydaje się być celowym kierowanie pracowników na serologiczne badania diagnostyczne, takie jak wykrywanie antygenu pałeczek Legionella $w$ moczu lub poziomu przeciwciał dla Legionella pneumophila w surowicy krwi.

\section{PIŚMIENNICTWO}

1. Breiman R.F., Butler J.C.: Legionnaires' disease: clinical, epidemiological and public health perspectives. Semin. Respir. Infect. 1998;13:84-89

2. Carratala J., Garcia-Vidal C.: An update on Legionella. Curr. Opin. Infect. Dis. 2010;23:152-157

3. Thorn J.: The inflammatory response in humans after inhalation of bacterial endotoxin: A review. Inflamm. Res. 2001;50:254-261

4. Rylander R., Bake B., Fischer J.J.: Pulmonary function and symptoms after the inhalation of endotoxin. Am. Rev. Respir. Dis. 1989;140:981-986

5. Zapór L., Gołofit-Szymczak M.: Czynniki biologiczne w środowisku pracy - ocena ryzyka zawodowego. Bezpiecz. Pr. 2008;2:6-9
6. Dutkiewicz J., Górny R.L.: Biologiczne czynniki szkodliwe dla zdrowia - klasyfikacja i kryteria oceny narażenia. Med. Pr. 2002;53(1):29-39

7. Stojek N.M.: Zagrożenia bakteriami z rodzaju Legionella $\mathrm{w}$ środowisku pracy. Podst. Metody Oceny Środ. Pr. 2004;3(41):61-67

8. Matuszewska R., Krogulska B.: Występowanie bakterii $\mathrm{z}$ rodzaju Legionella w obiegach wód chłodniczych. Rocz. Państw. Zakł. Hig. 2008;59(4):445-454

9. Krogulska B., Matuszewska R., Stypułkowska-Misiurewicz H., Pancer K.: Occurence of Legionella in water from dental units and estimation of antibiotic resistance of isolated strains. ASM Press, Washington 2002, ss. 295-297

10. Matuszewska R., Krogulska B.: Zagrożenie zdrowia ludzi związane z zakażeniem wód urządzeń chłodniczych i klimatyzacyjnych bakteriami z rodzaju Legionella. Med. Środ. 2002;5(Supl. 1):13

11. Sabria M., Yu V.L.: Hospital acquired legionelosis solution for a preventable infection. Lancet Infect. Dis. 2002;2:368-373

12. Kusnetsov J.M., Martikainen P.J., Jousimies-Somer H.R., VäIsäNen M.L., Tulkki A.J., Ahonen H.E. i wsp.: Physical, chemical and microbiological water characteristics associated with the occurrence of Legionella in cooling tower systems. Water Res. 1993;27:85-90

13. Rudbeck M., Viskum S., Moelbak K., Uldum S.A.: Legionella antibodies in a Danish hospital stuff with known occupational exposure. J. Environ. Public Health 2009: 812-829

14. Borella P., Bargellini A., Marchesi I., Rovesti S., Stancanelli G., Scaltriti S. i wsp.: Prevalence of antilegionella antibodies among hospital workers. J. Hosp. Infect. 2008;69:148-155

15. Hautemaniere A., Remen T., Mathieu L., Deloge Abarkan M., Hartemann P., Zmirou-Navier D.: Pontiac fever among retirement home nurses associated with airborne Legionella. J. Hosp. Infect. 2011;78:269-273

16. Napoli C., Tató D., Montagna M.T.: Assessment of occupational risk of Legionella sp. infection among dental health care personnel. Ig. Sanita Pubblica 2007;63:683-689

17. Tran Minh N.N., Ilef D., Jarraud S., Rouil L., Campese C., Che D. i wsp.: A community outbreak of Legionnaires' disease linked to industrial cooling towers - how far can airborne transmission spread. J. Infect. Dis. 2006;193:102-111

18. Gregersen P., Grunnet K., Uldum S.A., Andersen B.H., Madsen H.: Pontiac fever at a sewage treatment plant in the food industry. Scand. J. Work Environ. Health 1999;25:291-295

19. Bellido-Blasco J.B., Pelaz Antolin C., Delas-Gonzales M.A., Sarrión-Martinez J., Moreno-Muñoz M.R., Her- 
rero-Carot C.: Aggregation of casus of Legionella pneumonia in workers related to the ceramic industry in Castellon, Spain 2006. Rev. Esp. Salud Publica 2008;82:111-116

20. Castor M.L., Wagstrom E.A., Danila R.N., Smith K.E., Naimi T.S., Besser J.M. i wsp.: An outbreak of Pontiac fever with respiratory distress among workers performing high pressure cleaning at a sugar-beet processing plant. J. Infect. Dis. 2005;191:1530-1537

21. Fry A.M., Rutman M., Allan T., Salehi E., Benson R., Fields B. i wsp.: Legionnaires' disease outbreak in an automobile engine manufacturing plant. J. Infect. Dis. 2003; 187:1015-1018

22. Allen K.W., Prempeh H., Osman M.S.: Legionella pneumophila from a novel industry aerosol. Commun. Dis. Public Health 1999;2:294-296

23. PN-EN ISO 11731-2:2008 Jakość wody - Wykrywanie i oznaczanie ilościowe bakterii z rodzaju Legionella Część 2: Metoda filtracji membranowej dla wód o małej liczbie bakterii

24. PN-EN ISO 6222:2004 Jakość wody - Oznaczanie ilościowe mikroorganizmów zdolnych do wzrostu - Określanie ogólnej liczby kolonii metodą posiewu na agarze odżywczym

25. Nygård K., Werner-Johansen O., Ronsen S., Caugant D.A., Simonsen O., Kanestrøm A. i wsp.: An outbreak of Legionaires' disease caused by long-distance spread from an industrial air scrubber in Sarpsborg, Norway. Clin. Infect. Dis. 2008;46:61-69
26. Coetzee N., Liu W.K., Astbury N., Williams P., Robinson S., Afza M. i wsp.: Legionnaires' disease cluster linked to a metal product aqueous pretreatment process, Stafforshire, England, May 2008. Eurosurveillance 2009; 14:558-560

27. Joseph C.A., Harrison T.G., Ilijic-Car D., Bartlett D.L.: Legionnaires' disease in England and Wales: 1996. Commun. Dis. Rep. CDR Rev. 1997;7:R153-R159

28. Garasen H., Sagvik E., Kvendbø J.F., Lian A., Jacobsen T., Nylenna M.: Legionella in Trondheim, Norway - determining sources of contagion and tracing risk environment. Iddskr. Nor. Leageforen 2005;125:1791-1793

29. Kusnetsov J., Neuvoen L.K., Uldum S.A., Mentula S., Putus T., Tran Minh N.N. i wsp.: Two Legionnaires' disease cases associated with industrial waste treatment plants: A case report. BMC Infect. Dis. 2010;343:1-8

30. Ricketts K.D., Joseph C., Lee J., Wewalka G.: Survey on legislation regarding wet cooling systems in European countries. Eurosurveillance 2008;13(38):1-5

31. Ustawa Ministra Zdrowia z dnia 5 grudnia 2008 r. o zapobieganiu oraz zwalczaniu zakażeń i chorób zakaźnych u ludzi. DzU z 2008 r. nr 234, poz. 1570

32. Rozporządzenie Ministra Zdrowia $\mathrm{z}$ dnia 22 kwietnia 2005 r. w sprawie szkodliwych czynników biologicznych dla zdrowia $\mathrm{w}$ środowisku pracy oraz ochrony zdrowia pracowników zawodowo narażonych na te czynniki. DzU z 2005 r. nr 81, poz. 716

Ten utwór jest dostępny na licencji Creative Commons Uznanie autorstwa - Użycie niekomercyjne 3.0 Polska / This work is licensed under a Creative Commons Attribution-NonCommercial 3.0 Poland License - http://creativecommons.org/licenses/by-nc/3.0/pl/. 